\title{
IMPROVING LEARNING ACCESS FOR STUDENTS AND TEACHERS WITH E-LEARNING SYSTEM IN THE MITRA BINTARO JUNIOR HIGH SCHOOL, TANGERANG CITY
}

\author{
Achmad Solichin ${ }^{1 *}$, Haris Munandar ${ }^{1}$ \\ ${ }^{1}$ Faculty of Information Technology, Budi Luhur University \\ *achmad.solichin@budiluhur.ac.id
}

\begin{abstract}
Mitra Bintaro Junior High School is one of the private schools having its address at Tangerang City, Banten Province. Along with the development of information and communication technology (ICT), which is increasing rapidly today, Mitra Bintaro Middle School has an official website as one of the means of disseminating information for students, parents and the community. However, Mitra Bintaro Middle School does not have e-learning based learning media that can be accessed by teachers and students. This service activitywas held with the aim to implement an e-learning based learning system and train teachers and students in using E-learning at Mitra Bintaro Middle School. This training activity was divided into two sessions. In the first session, the material was delivered regarding the use of e-learning for teachers. Whereas in the second session the e-learning material was delivered to students of Mitra Bintaro Middle School. Participants are required to practice the material presented directly. With the implementation of the e-learning technology, the competency and access to learning for students and teachers of Mitra Bintaro Junior High School is easier and increasing.
\end{abstract}

Keywords: e-learning, junior high school, learning access, student, teacher

\section{INTRODUCTION}

The development of the information technology world has increased ever since the presence of internet network technology has connected hundreds or even thousands of local networks throughout the world. The internet provides a variety of conveniences as communication media and information sources that can be accessed more widely than conventional media. The internet has also encouraged the emergence of various technologies that facilitate work in various fields of life. One technology in education that is triggered by the presence of the internet is e-learning technology. By implementing elearning applications, can improve the effectiveness of learning. E-learning-based learning media can also encourage students to receive learning materials more efficiently and effectively.

According to Dobransky \& VanRy (2017), some of the advantages of e-learning are to save expenses in terms of development, time and place; suitable for specific topics; students can study anytime and anywhere; save 40-60\% compared to conventional learning methods; suitable for distance learning and mobile; and students can manage the appearance of learning material (can be accelerated or slowed). Based on other research, users also feel comfortable in using e-learning systems as learning media (Solichin, 2009).Figure 1 presents a comparison of E-Learning and traditional learning methods.E-learning has also been applied to improve the quality of learning and teacher competencies in various educational institutions. For example, Handoyo \& Sholeh(2011), organized e-learning training for social studies teachers in Genuk Sub-district, Semarang. In other studies, e-learning was successfully applied to Telkom Vocational School Sandhy Putra Purwokerto with a sufficient level of $77.27 \%$ (Hanum, 2013). Activities and student learning outcomes in SMA 10 of Jambi City also increased after the implementation of e-learning based learning systems(Aminoto \& Pathoni, 
2014).Based another study, the implementation of the "experiental" e-learning in Sanata Dharma University has a high level of user acceptance(Sedana \& Wijaya, 2012).

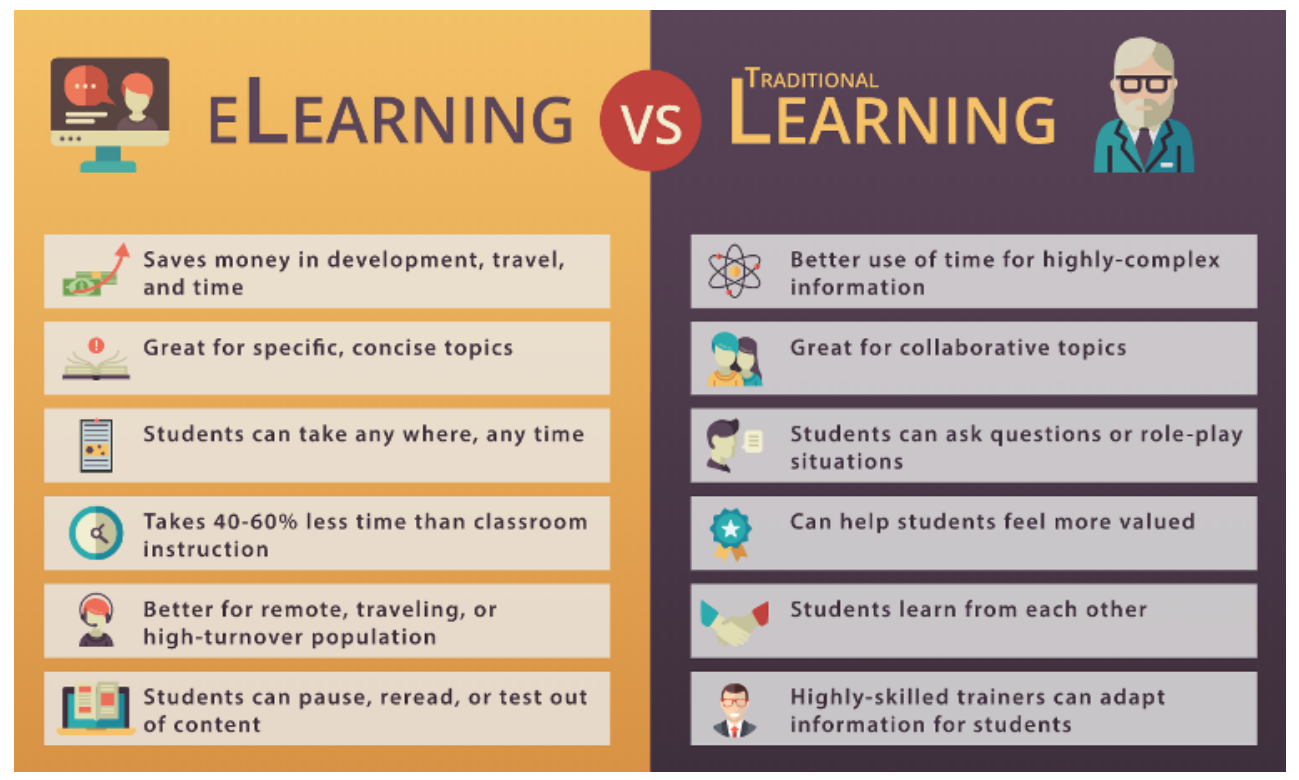

Figure 1: Comparison between E-learning and traditional learning methods (Dobransky \& VanRy, 2017)

The Mitra Bintaro Junior High Schoolisone of the private schools having its address at Tangerang City, Banten Province (SMP Mitra Bintaro, 2016). Currently,Mitra Bintaro Junior High School has an official site as a means of disseminating information for students, parents and the community. However, Mitra Bintaro Junior High School does not have an e-learning system. Based on the initial discussion with the headmaster, he wanted to improve the quality of learning through the application of e-learning systems.

This service activity aims to prepare and train teachers and students in using e-learning media at Mitra Bintaro Junior High School. Activities are divided into two stages: the system development stage; and socialization and training stages. The training itself was divided into two sessions: training for teachers and students .As one of the target schools that collaborates with the Budi Luhur University, the Mitra Bintaro Junior High School has held training activities to improve the competence of human resources and the quality of the learning process continuously. Training materials in the form of the application of e-learning systems in the teaching-learning process in schools.In activities that are one of the tangible manifestations of the Tridharma PerguruanTinggi (Three Pillars of Higher Education comprising Education, Research and Community Service), we want to help the community in the Mitra Bintaro Junior High School to improve the performance of teachers in e-learning methods. This activity has provided positive benefits for improving the quality of human resources and the quality of the learning process in schools.

\section{METHOD}

Training methods to convey theory include lectures, question and answer, and discussion. The practicum consists of a question and answer method and assignments. This method of training activities is carried out based on the theory and practice learning process approach. Comparison between theoretical learning and practical learning is $1: 2$. The following is a description of community service activities carried out in the Computer Laboratory, Mitra Bintaro Junior High School.

\section{Observation}


This program was carried out by visiting a service partner at the Mitra Bintaro Junior High School in Tangerang City to find out the partner's needs in the Community Service process. After knowing the needs of the partners, the lecturer formed a team for executing the program.

\section{Interviews}

Direct interviews were conducted with Mitra Bintaro Junior High School Headmaster, teachers, and staff about the needs that could be used as objects of community service.

\section{Study Literature}

Literature study is used to study various theories related to the theme of activities, documentation and searching information from various scientific resources regarding e-learning development activities.

Of the three methods of data collection above, we assemble the linkages between the activities we do between teams and users, as follows:

- The team conducted an analysis of the needs of users to the Mitra Bintaro Junior High School and discussed with related parties such as the Headmaster and the teachers.

- Lecturers make the results of a needs analysis by designing training needs.

- Lecturers create training modules that will be used as a guide for trainees.

- The lecturer prepares for the implementation of the training.

- Lecturers carry out training and evaluate the trainees by giving training.

The following are some materials related to e-learning based learning systems that will be given during training:

- Login and Enter the Course Page

- Adding Lecture Materials (Resources)

- Upload a Document File(s), PDF, Powerpoint, and other formats.

- Adding Material / Own Articles

- Add a Quiz

- Adding Exam Questions

○ Adding Multiple Choice Questions

- Adding Essay Questions

- Adding Questions from External Files (Import)

- Adding Questions to a Quiz

- Adding Assignments

- Student Evaluation

- See Online Quiz Results

- Assess the Assignment

- View the Overall Grade of Students

- Add Other Class Activities, including:

○ Discussion Forum.

- Activity Chat

\section{RESULT AND DISCUSSION}

Training in order to improve the quality of the learning process at Mitra Bintaro Junior High School through the implementation of the e-learning system has generally been going well and smoothly. Participants who attended were representatives of Teachers and Students. Participants also attended the training enthusiastically and passionately. However, several obstacles need to be solved in the future.

In general, the results that can be obtained from this training activity are participants can understand how the learning process through the e-learning system. Teachers can upload learning resources, manage exams or quizzes, manage assignments, manage and analyse the assessment results. Students can access, download learning resources and take exams. The e-learning system has been developed and implemented at the address http://elearning.smpmitrabintaro.sch.id. Each participant 
obtains a personal account to enter the e-learning system. Figure 2 shows the appearance of the elearning system of MitraBintaroJunior High School which has been filled with various subjects.

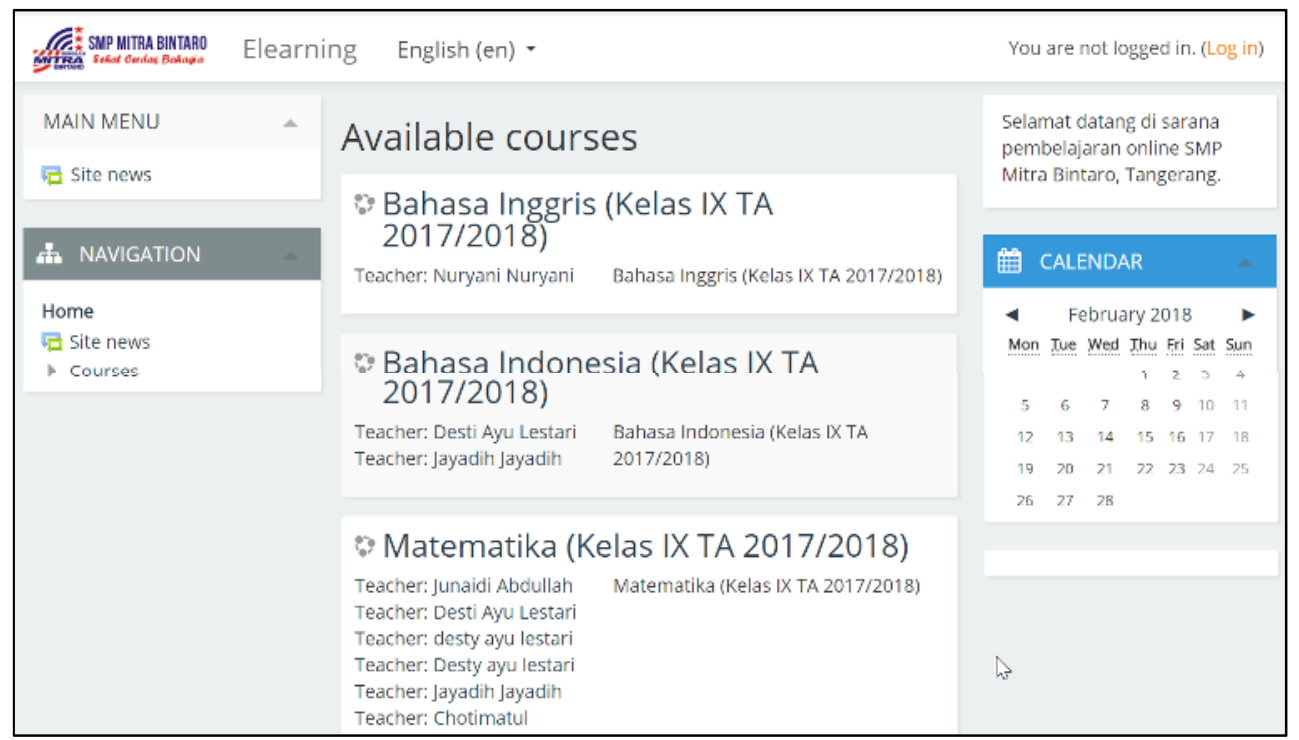

Figure 2: The E-learning Systems

Figure 3 shows an example of a Mathematics subject page for the Class IX of 2017/2018's Academic Year. On the subject page, the teacher can upload lesson material for each chapter. Students can only access subject resources and cannot upload subject them. In addition to resources, several activities that can be added on the courses page include exams/quizzes, discussion forums, chat, assignments and so on. By utilizing the e-learning system, students can access subject resources without being limited by the time and hours of study. Students can access subject resources from anywhere and anytime.

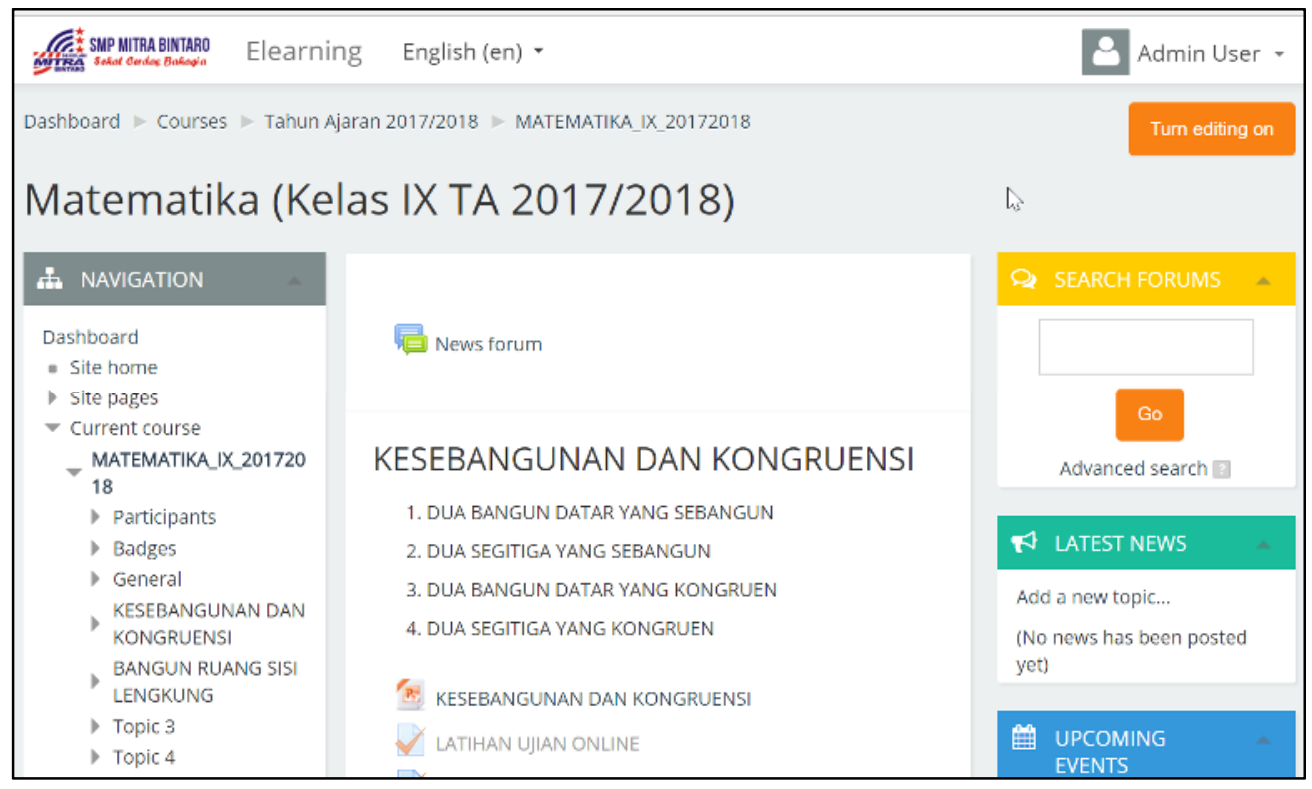

Figure 3: Examples of Mathematics Subjects in the E-Learning system 
Examples of quiz views in the E-Learning system appear in Figure 4. Students can complete the quiz within the time limit specified by the teacher. Quiz navigation is on the left screen, and some questions that must be workedare displayed. Students working time is also displayed in the navigation quiz section. Meanwhile, the problem is displayed on the main screen. To answer questions, students can choose or click the answer option for each question.

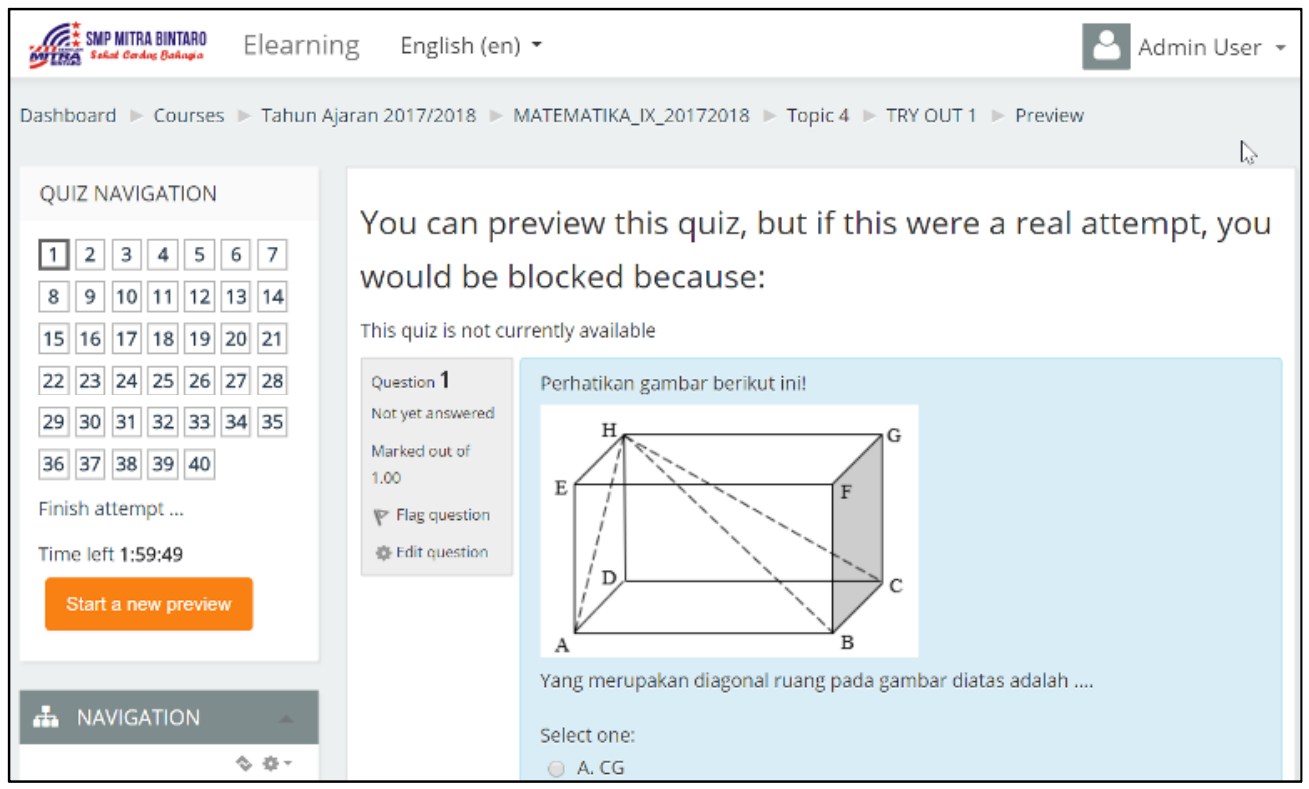

Figure 4: Examples of Quiz Pageviews in E-Learning Systems

Based on the results of the evaluation of the implementation of the training that has been carried out, it can be concluded that participants can feel the benefits of the implementation of this e-learning system training. Figure 5 shows the results of the evaluation of the implementation of training obtained using the questionnaire method.

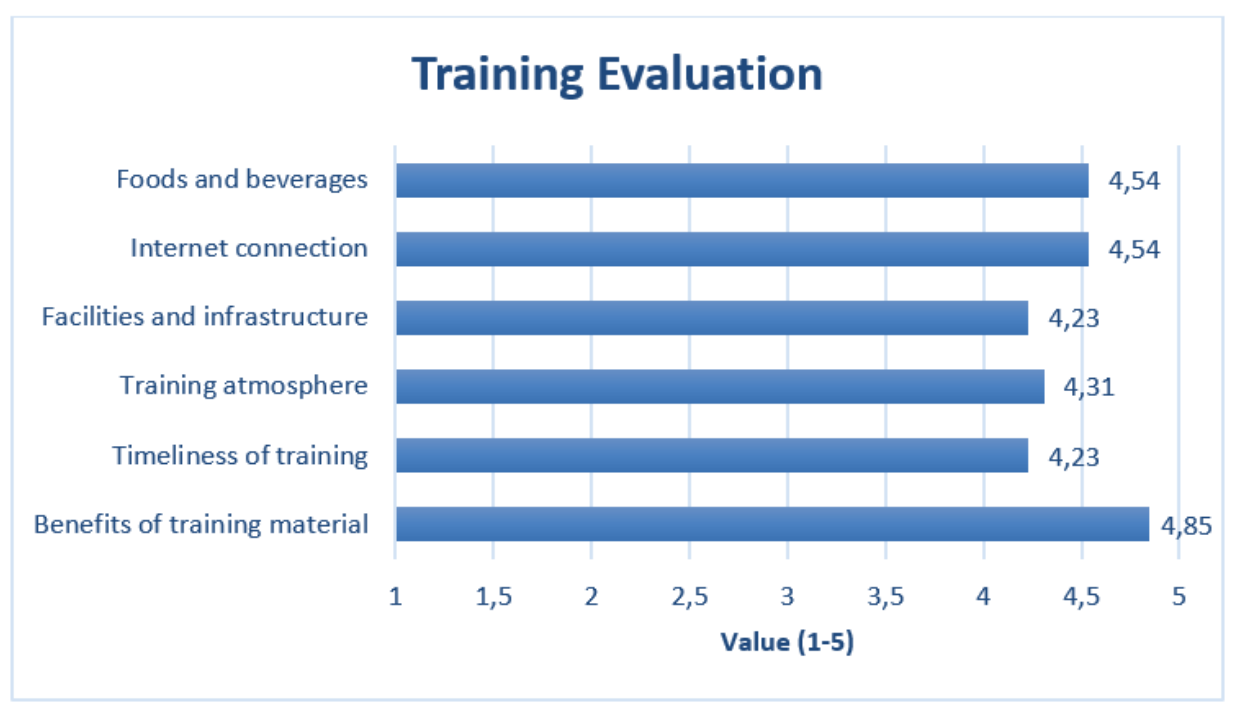

Figure 5: Results of Evaluation of Training activities 
The things that still need to be improved from the training activities are the timeliness of the training, the availability of training facilities and infrastructure such as computers, stationery and so on, as well as a comfortable training atmosphere. In general, the training participants' assessment of the training was at a goodlevel with a score of 4.45 in the 1-5 range.

Meanwhile, based on the participant's assessment of the instructor, it was seen that the participants were quite satisfied with the qualifications and resources presented by the instructor. It can be seen from the results of the training participants' evaluation of the speakers presented in Figure 6. In general, all participants considered that the customer had mastered the material very well. It can be seen from the results of the evaluation regardingmaterial mastery; the average value is 4.68 in the 1-5 range.Based on the results of the participant's assessment, things need to be improvedby the instructor, especially on how the instructor interacts with the trainees. Instructors must be more interactive in providing material by providing more opportunities for participants to ask questions and understand the material in greater depth.

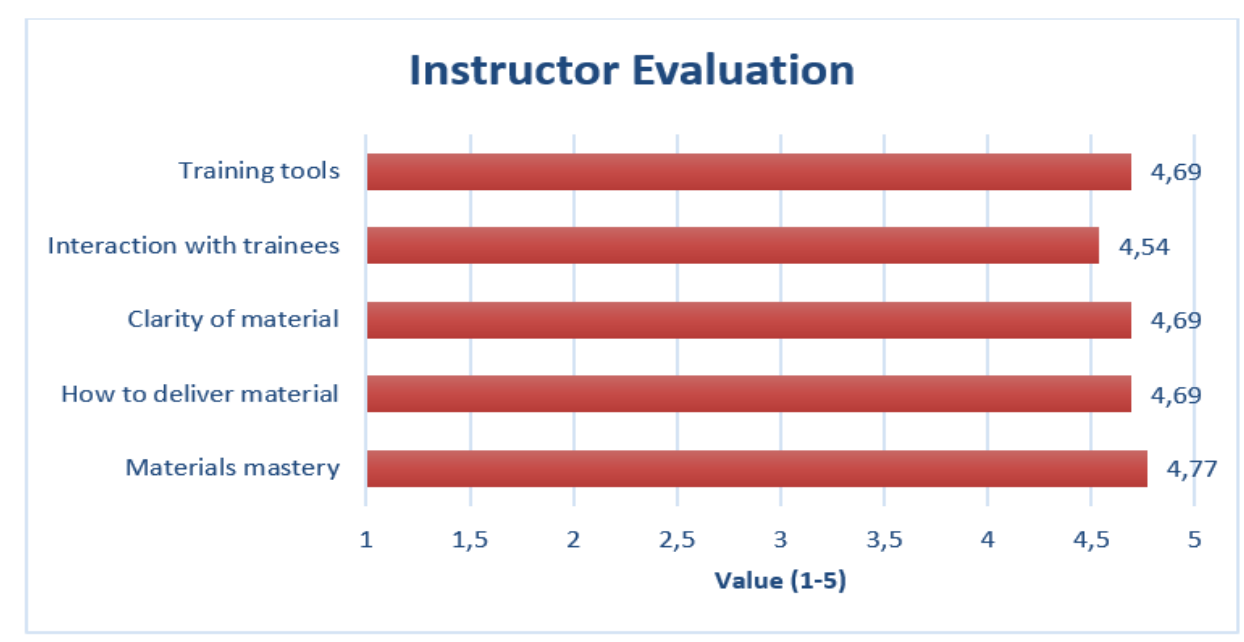

Figure 6: Evaluation Results of Training Participants on Instructors

Based on the results of the implementation of training and evaluation of the training, some things still need to be improved and improved in the future. Some notes on improving the quality of training in the future based on input from training participants include:

- Availability of training facilities and infrastructure must be considered, especially internet connections.

- The practice must be increased rather than theory.

- Future training will still be carried out with the more in-depth material.

- More improved and remain passionate about providing the knowledge they have to make it more useful for many people.

- For training in the future, it is expected that the discussion material will be denser.

- Increase again regardingresources delivery.

- Further activities need to be improved.

Also, the implementation time also needs to be considered in conducting training. The selection of the right time for activities will make the results of the training useful. Some training materials cannot be delivered because of limited time to run. Training facilities and infrastructure can also be obstacles and need to be anticipated. One of the most important is an internet connection because the training material is directly related to the availability of internet services.

\section{CONCLUSION}


Based on the implementation and evaluation of training implementation, in general,several things canbe concluded, namely:

1. The implementation of the training went smoothly and was attended by trainees from students, teachers, andthe headmaster of MitraBintaroJunior High School

2. The training material presented is how to use e-learning technology in the learning process in schools, so that the material can be delivered more effectively and efficiently.

3. The evaluation results indicate that the trainees feel the benefits of the material provided. The average value of training is 4.45 , and the assessment of instructors is 4.68 in the $1-5$ range.

Meanwhile, the quality of training needs to be improved in the future. Some suggestions for the implementation of community service activities in the future:

1. The material presented in training should be more precise and more structured.

2. Material tailored to the needs and competencies desired by the institution.

3. The selection of training days should be appropriately considered so that material delivery is more effective and efficient.

\section{REFERENCES}

Aminoto, T. (2014). Penerapan Media E-Learning Berbasis Schoology Untuk Meningkatkan Aktivitas dan Hasil Belajar Materi Usaha dan Energi Di Kelas XI SMA N 10 Kota Jambi. Sainmatika: Jurnal Sains dan Matematika Universitas Jambi, 8(1).

Dobransky, M., \& VanRy, N. (2017). Instructor-led Training vs. eLearning. Retrieved January 3, 2018, from https://www.edgepointlearning.com/blog/instructor-led-training-vs-elearning/

Handoyo, E., \& Sholeh, M. (2011). Pelatihan Better Teacher And Learning Bagi Guru IPS SMP dan Mts Swasta di Kecamatan Genuk Kota Semarang. Jurnal Abdimas, 15(1).

Hanum, N. S. (2013). Keefetifan E-Learning sebagai Media Pembelajaran (Studi Evaluasi Model Pembelajaran E-Learning SMK Telkom Sandhy Putra Purwokerto). Jurnal Pendidikan Vokasi, $3(1)$.

Sedana, I. G. N. (2009). Penerapan model UTAUT untuk memahami penerimaan dan penggunaan learning management system studi kasus: Experential e-learning of Sanata Dharma University. Jurnal Sistem Informasi, 5(2), 114-120.

SMP Mitra Bintaro. (2016). SMP Mitra Bintaro. Retrieved August 13, 2018, from www.smpmitrabintaro.sch.id

Solichin, A. (2011). Mengukur Tingkat Kenyamanan Penggunaan Sistem E-Learning Moodle dalam Proses Knowledge Sharing: Studi Kasus di Universitas Budi Luhur. Jakarta: Fakultas Teknologi Informasi, Universitas Budi Luhur, Tanpa tahun. 